\title{
(165)
}

\section{Landslide and Subsidence Potential due to the Progressive Development of Cave Network in Ella-Wellawaya Area, Sri Lanka}

\author{
P. Jayasingha ${ }^{1,2 *}$, G. Jayathissa ${ }^{2}$, R.M.S. Bandara ${ }^{2}$, W.S. Weliange ${ }^{1,3}$, R.A.L. \\ Osborne $^{1,4}$, A.S. Dandeniya ${ }^{1}$, A.K.P.P. Algiriya ${ }^{1}$, S. Senanayake ${ }^{1}$, M. Champika ${ }^{1}$, \\ N.S. Prasannajith ${ }^{1,5}$ \\ ${ }^{1}$ Lanka Institute of Cave Science, Sri Lanka \\ ${ }^{2}$ National Building Research Organisation, Sri Lanka \\ ${ }^{3}$ Department of Zoology, University of Ilorin, PMB 1515, Nigeria \\ ${ }^{4}$ Education and Social Work, A35, University of Sydney, NSW, 2006, Australia, \\ ${ }^{5}$ Archives and Documentation Centre, University of Ilorin, PMB 1515, Nigeria \\ *jpathmak@gmail.com
}

\begin{abstract}
Carbonate rocks are highly soluble. Sinkholes are formed by both the failure of solution cavities and the rapid removal of fines from solution cavities in carbonate and metacarbonate rocks. Sri Lankan landmass is composed of Proterozoic high-grade metamorphic rocks such as gneiss and metacarbonates like marble. Large caves in Sri Lanka form in both marble and gneiss. A few land subsidence events have occurred recently in Ella-Wellawaya area, which is a hilly terrain. In addition, some cases of groundwater table lowering, which has caused drying of dug wells have also been recorded within the area, apparently related to a major development project presently under way in the area.

The main objective of this paper is to draw the immediate attention of local researchers and authorities whom are working on mitigation and management of disasters, groundwater and climate change, showing the importance of carrying out detail studies on potential landslides and land subsidence of Ella-Wellawaya area for avoiding and minimising loss of humans and properties. Preliminary surveys on some land subsidence cases and speleological studies including geology, hydrogeology and morphological mapping of the underground caves in the area have been actively carried out. According to the results, it is shown that the subsidence is likely to be correlated with the collapsing of cavities and weathered zones in metacarbonates, and disturbances to the groundwater table. Field explorations done during the last two years have discovered several large underground caves in the area some more than $100 \mathrm{~m}$ across. Most of the cave roofs have been thinned by the breakdown of bedrock along weak zones such as joints. Since the process of collapse, trigged by weathering is continuing and patches and lenses of carbonate rocks observed in the caves are still being dissolved, the expansion of the cave spaces is unending. Some of the chambers of these caves are aligned parallel to the steep slopes in the Ella-Wellawaya area and some acted as underground water conduits and storages during the rainy seasons. The Ella-Wellawaya area has been undergone a change in vegetation cover since the colonial period and hence the area is more prone to soil erosion which exposes the near surface natural cavities to the underground caves. Present human exposures and interactions within the susceptible slopes have brought lives and properties under threat. Hence future land subsidence and landslide occurrences are highly predictable with the recent conditions in the area and hence threat to human life and properties is high. The tourism industry, unique to the area could particularly be affected. Hence such hazardous should properly be identified and demarcated and the erosion triggered by present vegetation changes must properly be addressed.
\end{abstract}

Keywords: Metacarbonate rocks, Subsidence, Ella-Wellawaya, Cave network, Erosion

Proceedings of the International Forestry and Environment Symposium 2015 of the Department of Forestry and Environmental Science, University of Sri Jayewardenepura, Sri Lanka 